2012-03-09

\title{
Teachers as mediators: an exploration of situated English teaching
}

Kelly, Peter

http://hdl.handle.net/10026.1/1544

10.1080/01411926.2012.665433

British Education Research Journal

Routledge

All content in PEARL is protected by copyright law. Author manuscripts are made available in accordance with publisher policies. Please cite only the published version using the details provided on the item record or document. In the absence of an open licence (e.g. Creative Commons), permissions for further reuse of content should be sought from the publisher or author. 
This article was downloaded by: [Peter Kelly]

On: 09 March 2012, At: 02:14

Publisher: Routledge

Informa Ltd Registered in England and Wales Registered Number: 1072954 Registered

office: Mortimer House, 37-41 Mortimer Street, London W1T 3J H, UK

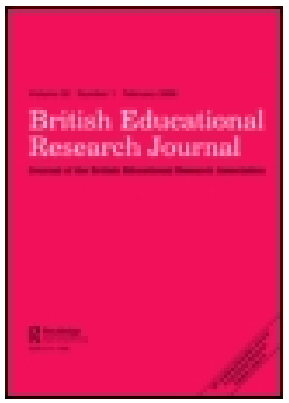

\section{British Educational Research J ournal}

Publication details, including instructions for authors and subscription information:

http:// www.tandfonline.com/loi/ cber20

\section{Teachers as mediators: an exploration of situated English teaching}

Peter Kelly ${ }^{a}$, Ulrike Hohmann ${ }^{a}$, Nick Pratt ${ }^{a} \&$ Hans Dorf ${ }^{b}$

a Plymouth University, Plymouth, UK

${ }^{\mathrm{b}}$ Aarhus University, Copenhagen, Denmark

Available online: 09 Mar 2012

To cite this article: Peter Kelly, Ulrike Hohmann, Nick Pratt \& Hans Dorf (2012): Teachers as mediators: an exploration of situated English teaching, British Educational Research J ournal, DOI: 10. 1080/ 01411926. 2012.665433

To link to this article: http:// dx. doi.org/ 10.1080/01411926.2012.665433

\section{iFirst}

\section{PLEASE SCROLL DOWN FOR ARTICLE}

Full terms and conditions of use: http://www.tandfonline.com/page/terms-andconditions

This article may be used for research, teaching, and private study purposes. Any substantial or systematic reproduction, redistribution, reselling, loan, sub-licensing, systematic supply, or distribution in any form to anyone is expressly forbidden.

The publisher does not give any warranty express or implied or make any representation that the contents will be complete or accurate or up to date. The accuracy of any instructions, formulae, and drug doses should be independently verified with primary sources. The publisher shall not be liable for any loss, actions, claims, proceedings, demand, or costs or damages whatsoever or howsoever caused arising directly or indirectly in connection with or arising out of the use of this material. 


\title{
Teachers as mediators: an exploration of situated English teaching
}

\author{
Peter Kelly $^{\mathrm{a} \star}$, Ulrike Hohmann ${ }^{\mathrm{a}}$, Nick Pratt ${ }^{\mathrm{a}}$ and Hans Dorf ${ }^{\mathrm{b}}$ \\ ${ }^{a}$ Plymouth University, Plymouth, UK; ${ }^{b}$ Aarhus University, Copenhagen, Denmark
}

\begin{abstract}
Within the context of lower secondary English teaching in South West England, this study identifies in broad terms the competing goals between which English teachers mediate and the explicit and hidden tensions that result. To understand the interactions of competing goals, teachers' goal-oriented behaviours are referenced to a set of idealised 'role types' based on the dimensions of goals, norms, discourses and practices. It is asserted that competing goals, significant to particular educational circumstances, emanate from various sometimes contradictory local, national and perhaps broader social and cultural influences on practice. Yet the teachers observed moved smoothly between goal-oriented behaviours in a continuous and comfortable style, easily and without reflecting any tensions between them. Thus, this article elaborates an account of situated English teaching.
\end{abstract}

Keywords: English teaching; situated teaching; teacher mediations

\section{Teaching as a culturally situated activity}

As the ultimate implementers of education policy (Croll, 1996), teachers have a major influence on student experience and classroom practice. Much comparative research (Broadfoot \& Osborn, 1993; Osborn, 1996, 2006; Osborn et al., 1997, 2003; Tatto \& Mincu, 2009; to name just a few) suggests the specific political economies of countries and different systemic and accountability structures within which teachers work give rise to different conceptions of teaching; indeed, different professional identities which are evident in both their working practices and espoused beliefs. Taking such research as our starting point, we assume that teaching is socially and culturally situated at a macro-sociological level and seek to explore this micro-sociologically.

\footnotetext{
${ }^{\star}$ Corresponding author. Faculty of Health, Education and Society, Plymouth University, Drake Circus, Plymouth PL4 8AA, UK. Email: peter.kelly@plymouth.ac.uk
} 
This study focuses on one context, lower secondary English teaching in South West England, to explore the enactment of that macro-social situatedness, identifying in broad terms the competing goals between which English teachers mediate and the explicit and hidden tensions that result. We assert that competing goals emanate from a wide variety of sometimes contradictory local, national and perhaps broader social and cultural influences on practice.

Our approach is not evaluative; it is exploratory and descriptive. We are not judging, for example, the relative merits of different outcomes or valorising particular practices. Nor is our concern the consistency of teachers' practices with their espoused beliefs. Rather, we see the many influences on teachers' practice being in constant interplay and competition with each other, and assume that by looking at what teachers actually do we can describe which of the expected outcomes are most influential at any one time and consider those areas where practices leading to different outcomes interact and compete. Whilst this study explores lower secondary English teaching, it is illustrative of processes of mediation that are much broader, concerning not only subject-specific outcomes, but also those relating to areas such as class management, lifelong learning, and the construction and maintenance of professional identities. Thus whilst some would contend it impossible to evaluate formal aspects of an English lesson without considering what has been learnt about the subject, we suggest that this is just one outcome amongst many to which teachers attend in the routines of their everyday practice.

\section{Studies of English teaching}

In seeking to understand teaching, expertise has been the focus of much research. Some have tried to identify common non-contextual features of experts, both broadly (Glaser, 1987, 1990; Greeno et al., 1996)—on which Dreyfus and Dreyfus' (1986) typology of developing expertise is based-and specifically in teaching (Fish, 1995; Beijaard \& Verloop, 1996; Day, 1999; Christie, 2003). Others have focused on teachers' pedagogical knowledge, philosophies, values and disciplinary understandings (Shulman, 1986, 1987; Summers, 1994; Osborne \& Simon, 1996; Harlen, 1997; DfEE, 1998; Marshall, 2000; Turner-Bissett, 2001; TTA, 2002; reviewed in Ellis, 2007).

Ellis (2007) is concerned by the objectivism of such research. He reports that more recent work linking effective teacher practices to assessed student outcomes has sought to avoid this objectivism by focusing on practices embedded and validated in communities. Whilst some (such as Lowman, 1996) have explored these generally, more have adopted a subject-specific focus; for example, in literacy teaching in Australia (Wyatt-Smith \& Gunn, 2007) and the UK (Medwell et al., 1998), and English teaching in the USA (Moats, 1999). In this regard, we note the extensive evaluative case-study literature concerning secondary English teaching, which often resists narrow subject perspectives or simplistic notions of effectiveness, with much innovative and inspirational practice to be found in journals such as English in Education, Changing English and English Teaching: Practice and Critique. 
Whilst recognising the usefulness and importance of the work cited above, we make three observations that provide a point of departure for the present study. First, whilst accepting Ellis' (2007) sociocultural account, we see teachers' subject knowledge-of-practice (Schön, 1983, 1987), including their philosophies, values and disciplinary understandings, rather than being central, as being one of many contributors to the complex web of influences across which teachers have to mediate. Second, whilst acknowledging the importance of teachers' knowledgein-practice (Schön, 1983, 1987), their tacit embedded ways of acting (Sternberg \& Horvath, 1999) described by researchers like Medwell and her colleagues (1999), such accounts concern the individual practitioner who, whilst conversing with their practice, personally possesses both knowledge-of-practice and in-practice. Our view is that this perspective is unbalanced; that knowing is distributed across people and settings (Lave, 1991; Pea, 1993). Finally, it is our contention that the majority of case studies are based in idealisations of very specific notions of subject teaching. Our intention in this study is to look at teaching embedded in the practicalities and messiness of routine practice.

\section{Ways of knowing}

Lave and Wenger (1991), Wenger (1998) and Billett (2001) argue for a view of both coming to know and knowing-in-practice as processes which, rather than lying entirely with the individual, are distributed across all participants in social settings (in the case of the English classroom, teachers and students). These ways of knowing relate to:

- the explicit conceptual resources that teachers bring, which might, in this case, include their knowledge and beliefs about English, their knowledge of pedagogical approaches and their knowledge of common misconceptions students have when learning English

- the tacit understandings gained from previous teaching and related experience, which might include using a variety of clues to get a feel for when a child needs help or encouragement

- the resources provided by the classroom, including whether it lends itself to individual or collaborative group work, and whether students have access to a range of resources including computers

- the conceptual resources and tacit understandings that students bring, including their prior learning, their beliefs about English and their disposition to particular learning approaches.

Teachers' and students' knowing-in-practice (Billett, 2001) or knowledgeable activity in the lesson results from the iteration between these. In formal schooling, teachers in classrooms engage with their students' knowledge of English through the practices of classrooms. Thus the students come to know English as pupils. Their way of knowing is that of pupils because they engage with English 
knowledge through the working practices of pupils. As Wenger (1998, p. 267) puts it, all too often 'school learning is just learning school'.

Bethan Marshall (2003) describes ways of knowing in English classrooms which currently dominate:

the attempt to outline the content of the subject has led to a concentration on knowledge that is apparently factual and formulaic - through itemising desired competencies in certain linguistic and generic conventions. (2003, p. 83)

She suggests how this is socially and politically constructed:

the teaching of conventions becomes an end in itself ... In a world of target setting, accountability and new managerialism, where all must be unequivocal and transparent, a framework that outlines in definable detail the apparently teachable substance of what is at best a very vague subject has its appeal. Moreover, it gives a certainty to the stages of progression. (2003, p. 93)

But there are alternative ways of knowing that we might consider more desirable, such as:

an understanding which is predominantly aesthetic - through the interplay between literary appreciation and creative writing, the relationship between reader and writer. (2003, p. 83)

If we accept such notions, then when teachers' practices contribute significantly to the advance of specific, valued aspects of student performance, they do so in consort with the conceptual resources and agendas their students bring and the physical assets of the environment in which they work. Teachers are therefore one element, albeit an extremely significant one, in enabling influential but contingent socially situated outcomes to be realised, many of which are assigned to their students.

\section{Teacher competence and educational goals}

For Lave and Wenger (1991), participants in a community of practice share socially negotiated goals and expectations, discourses and working practices. As such, teachers work in several communities of practice including the school, the staffroom and the classroom. In each of these their work is oriented by particular motives, towards the achievement of particular goals within certain contextual conditions (Engeström et al., 1999; Leont'ev, 1981) (for clarity in this study we do not separate motives from goals, and refer to socialised conditions as norms, comprising implicit and explicit socialised expectations including customs, guidelines, laws, morals, policies, principles, rules and the like). In so doing they use particular discourses to frame, understand and negotiate their practice and adopt particular working practices.

It is in participating in such communities that teachers develop their professional identities. Novices' participation in communities is described as peripheral, but as they gain competence their participation becomes more central (Wedege, 2002). 
Note that there is no assumed link here between the notion of being a competent teacher and that competence being reducible to a set of instrumental competencies. Competent teachers, that is central players fluent in the norms, discourses and practices of their community, work with others in their communities towards the successful achievement of important outcomes for their communities (Kelly, 2006); their activities in combination with those of their students enable students to achieve as highly as they can in relation to the parameters deemed important within their educational context. Individual teachers may be competent in some situations - say with a particular age of student, in a particular subject, or in a school serving a particular socioeconomic community-but not others, and some teachers may be competent in more situations than others. In this regard, a competent teacher of English may help to prepare students well for end-of-year examinations so that they achieve highly, but may also gain positive reports from students and parents in a system where such accountability is valued highly. But in a system where continued post-compulsory study is valued highly, the same teacher may lack competence-someone able to inspire a love of the subject and provide insights into its beauty and elegance may do better.

However, teachers' work is also embedded in wider social, cultural and historical contexts, and as such educational communities are not static and have many goals, norms, discourses and sets of practices, potentially in competition with each other; they are dynamic, with teachers constantly engaged in an ongoing mediation between different factors, re-negotiating their competence. As Ball puts it, 'teaching has always involved making decisions within a complex and rich field of contradictions, dilemmas and priorities' (Ball, 2006, p. 83; see also Berlak \& Berlak, 1981). In these mediations teachers' professional identities are important; that is, how teachers identify and position themselves and believe they are identified and positioned by others. These may pertain to areas such as the subject they are teaching, the teaching approaches they use, and their view of how students learn best. Professional identity concerns questions such as: What kind of a teacher am I? What is important to me in teaching? Which ways of working do I identify with? How do I view different subjects?

So, returning to Marshall's (2003) analysis, a competent teacher of English in an English school is able, amongst other things, to work with students so that they score highly in assessments of their literacy attainment and national tests in particular. To do this they might frame their practice with talk of targets and next steps, and might adopt practices that involve working with the whole class on comprehension, grammatical or composition exercises addressing key ideas and then giving appropriate tasks to groups of students selected according to their identified areas of strength and weakness. All of this activity is oriented towards improving students' assessment performance. But government initiatives may mean that each year national tests change (perhaps towards using more poetry in comprehension and writing exercises) or particular groups of students have a greater focus (perhaps those from a particular underachieving group). Also, reflecting on the findings of educational research the school may seek to increase student discussion 
and self-assessment in all areas (including literacy) as a matter of policy. Further, teachers' own motives, beliefs, expectations and professional identities are important; a teacher who holds dear the aesthetic that Marshall describes above and seeks to counter the reduction of English to literacy or test outcomes, might focus on engendering a love of literature and sense of wonder from it.

The competent teacher has to mediate between each of the above whilst still meeting important goals within the affordances and constraints of their working environments:

- a particular school: be it in an inner-city or a rural setting, serving an area of privilege or disadvantage

- a particular classroom or learning environment: be it an old or a new classroom, a well- or an under-resourced one

- with pressures from particular interested parties: be they parents, students, teaching assistants, colleagues, senior managers, advisors or school inspectors.

\section{Analysing teacher mediations}

Fuelled by limitations of time and resource, these various influences, differing in status, may be in competition, contradiction or conflict with each other; living with and wherever possible reconciling such tensions is central to many teachers' day-to-day experience. Bernstein (1990, 1996) saw schooling, which he called the reproduction field, as a social space of conflict and competition, and described the workings of power and control in this field. To unpick teacher mediations in this study we use three elements of pedagogic discourse identified by Bernstein. First, Bernstein argues that we can distinguish between overt or official curriculum experiences and those that are hidden or covert, which he terms visible and invisible pedagogies (Bernstein, 1973, 1996). These are partly defined by their goals and goal orientations. In this study we examine not just the explicit goals reported by teachers, but also those less discernible goals, towards which classroom norms, discourses and practices are oriented. Secondly, we consider classroom motives, goals and norms, visible or invisible, in terms of two elements of pedagogic discourse: instruction, which concerns the content of teaching; and regulation, which concerns managing the division of labour and promoting appropriate conduct in the classroom (Bernstein, 1990).

Finally, in examining power relations concerning which motives, goals and norms dominate in participants' interactions, we invoke two principles (Bernstein, 1996): classification, being the strength and weakness of borders between categories such as phases of school, subjects, or academic and vocational approaches, any movements in this and the work of boundary maintenance; and framing, indicating who has control over, for example, sequencing and pacing the teaching and learning interaction. When the control is with the teacher the framing is strong, whereas in weak framing the student appears to gain more control. Between each, consideration is given to issues of porosity and insulation. 


\section{Ideal types}

As social researchers we want to identify patterns in complex social practice, allowing implications to be drawn with some confidence, without losing the richness and messiness of real life. Weber proposed the notion of 'ideal types' with this in mind: to act as a bridge between generalising and recognising uniqueness in social inquiry (Weber, 1949; Crotty, 1998). Ideal does not refer to perfect things, moral ideals or statistical averages; it refers to the world of ideas, and ideal types are idea-constructs that help to put the chaos of social reality in order (Weber, 1949). Whilst ideal types are formed by describing and interpreting the characteristics of a given phenomenon, they stress certain elements common to most cases of that phenomenon rather than correspond to all of the characteristics of any one particular case. As such, Weber stresses, one cannot claim validity for an ideal type in terms of a reproduction of or a correspondence with social reality; rather, one has to look to the resonance of ideal types with lived experience, guiding the social inquirer in their consideration of real-life cases to reveal what is 'possible and adequate' (Weber, 1970, p. 323). Therefore, the construction of ideal types cannot be separated in the data analysis from their subsequent application as a lens for understanding everyday social activity. Ideal types cannot be considered in isolation; they only make sense through their use as a tool for viewing real life and comparing cases (Weber, 1949).

Crotty (1998) points out that, in using the notion of ideal types, researchers must be cognisant of the need to avoid providing causal explanations for social phenomena. We do so by maintaining that ideal types are metaphorical and not literal constructs. Through their comparison to lower secondary school English classrooms, we can infer patterned or structured behaviours across both visible and invisible pedagogies (Bernstein, 1973) concerning both instruction and regulation (Bernstein, 1990). And by tracing the interplay between implied behaviours we can shed light on power relations (Bernstein, 1996).

\section{Teacher roles}

For Weber, ideal types concern rational goal-oriented conduct (Weber, 1949); it is to this end that we use them here. Ideal types are constructed from various data gathered to describe the goal-directed behaviours of English teachers in naturalistic settings, interpreted using Bernstein's pedagogic device (1990, 1996). Types then act as lenses, often in combination with each other, through which we view real cases. But both Weber and Bernstein privilege individuals above social relations. For us, as has already been discussed, knowledgeable activity in lessons results from iteration between teachers and students within the affordances and constraints of particular environments. As such, we wish to describe goal-directed behaviours in terms of relational processes, and to do so invoke the notion of roles as a social unit of analysis. 
Teacher roles are situated enactments of goal-directed practice, but it is not simply in the gift of teachers to adopt and act out their preferred roles. Indeed, we do not assume an essential actor behind roles. Teacher roles respond both to the roles adopted by students and to the affordances and constraints of the subject, the classroom, school culture, other interested parties, and so on.

In summary, this study seeks to adopt a perspective that recognises social complexity. We focus on teaching as one particular and significant influence on variations in student achievement. We identify in broad terms the competing goals between which English teachers mediate and the explicit and hidden tensions that result. We assert that they do this in iteration with their students, within the affordances and constraints of their working environments and influenced by professional cultures and identities. To understand the interactions of competing goals we consider teachers' goal-oriented behaviours or roles. By focusing on competent teachers we hope to identify roles uncluttered by issues of personal proficiency. To explore these mediations we first identify idealised teacher role types by describing both explicit goal-directed behaviours and those that can be inferred from contextual norms and from classroom discourse and practices, and analysing these in terms of the classification and framing of instructional and regulatory discourses. We then use constructed role types as lenses to view real cases and clarify the influence of power relations on teacher mediations.

\section{Method}

The present study is set in the context of lower secondary school English teaching in South West England. English was chosen because over the past 20 years it has been the site of much reform. Consequently, it is an area where policy and guidance have proliferated, together bringing much policy tension and confusion. As a core area of student learning attracting much political attention, it continues to provide a significant site of contestation. We looked at teachers of children in the school year in which they were 12 (Year 8 in England). This allowed consideration of subject teaching beyond basic level, but avoided working with teachers focused entirely on test preparation. The focus was on eight teachers in four separate schools (that is, two from each school). Schools were identified by local authority advisors as those with consistently high levels of success in published English examination results. They had between 600 and 1500 pupils on roll, with one serving an inner-city and socioeconomically disadvantaged catchment and the others serving town and rural contexts with mixed catchments. With the exception of one school which was ethnically mixed, pupils attending were largely white British. All had been graded either good or outstanding in their most recent Ofsted inspection. Schools divided pupils into separate classes or sets according to their attainment; teachers in this study were observed teaching either middle or top sets.

Participating teachers were those identified as promoting high student attainment in English assessments by school managers. They had between 3 and 15 years' experience, three were male and five female, and their ethnic mix reflected 
that of the schools in which they taught. All were specialist English teachers. Two were Advanced Skills Teachers, with a wider staff development role across their local authority, and another was Head of English. Two had become teachers after pursuing other careers, and another had trained to teach after a period of employment as a teaching assistant. Three of the teachers expressed ambitions to one day become school principals.

Following the comparative work cited earlier, we recognise there are many macro-sociological influences on the construction of teaching. These include the nature of society that schools serve in terms of ethnicity, social class, gender, inequality and social mobility, and the role of families; the value society places on education and schools; and the importance society places on particular educational achievements. We accept that each of these (and many other similar features) cannot be analysed separately in a study such as this, but seek rather to focus on a micro-sociological analysis of pedagogic practice in the classroom.

\section{Data collection}

This is summarised in Table 1. During the summer term 2009 two lessons for each teacher, each relating to a slightly different context (for example, a different ability class, a different content area, and so on) were observed and audio recorded during a three-week period (first in week 1 and second in week 3), and on each occasion both the teacher's planning and samples of the students' work were collected. Following each lesson the observer's notes, audio recording of the teacher in the lesson, planning and children's work provided the basis for lesson analysis (see Table 2). Immediately following each lesson a detailed interview was used to further explore and illuminate teachers' goals (conditioned by contextual norms), discourses and practices. Participating teachers were asked to reflect on their teaching between visits. Their reflections were used as a basis for additional

Table 1. Linking the sociocultural focus to data collection methods and data

\begin{tabular}{|c|c|c|}
\hline Focus & Method & Data \\
\hline $\begin{array}{l}\text { Practice of those identified as } \\
\text { competent in teaching English }\end{array}$ & $\begin{array}{l}\text { Lesson } \\
\text { observations } \\
\text { Detailed } \\
\text { artefact } \\
\text { mediated } \\
\text { interviews }\end{array}$ & $\begin{array}{l}\text { Consideration of a group of competent teachers } \\
\text { of English: two lessons for each teacher } \\
\text { observed, and the teachers' planning and } \\
\text { students' work collected and used as the basis } \\
\text { for detailed interviews to illuminate teachers' } \\
\text { goals, discourses and practices }\end{array}$ \\
\hline $\begin{array}{l}\text { Reflections of those identified } \\
\text { as competent in teaching } \\
\text { English }\end{array}$ & $\begin{array}{l}\text { Detailed } \\
\text { artefact } \\
\text { mediated } \\
\text { interviews }\end{array}$ & $\begin{array}{l}\text { The same competent teachers were asked to } \\
\text { reflect on their practice in a further extended } \\
\text { interview after the second lesson observation to } \\
\text { illuminate their processes of decision making in } \\
\text { the light of their professional identities }\end{array}$ \\
\hline
\end{tabular}


Table 2. Examples of lesson analysis prompts for identifying teachers' goals, norms, discourses and practices

\section{Goals and norms}

What does the teacher say the lesson is about; what are the explicit aims of the lesson?

What are the teacher's expectations in what $\mathrm{s} /$ he says and does?

What does $\mathrm{s} /$ he praise? What does $\mathrm{s} /$ he critique?

What does the work set say about the teacher's expectations?

What do the teacher's instructions and interactions say about the teacher's expectations?

What does the children's response say about their expectations, and how does the teacher respond to them?

Are these static, or are they negotiated?

Discourse

What subject/teaching specific language does the teacher use?

What does the teacher say or do which suggest his/her view of teaching and learning?

Practices

What is the teaching space like? How does it help/hinder the teacher and children's activity?

Which resources are used and how are they used?

How is the classroom organised (whole class, groups, individuals; didactic, interactive,

collaborative, problem based)?

What tasks are given?

What instructions does the teacher give?

questions at the end of the second interview to explore their decision-making processes in the light of their professional identities.

\section{Data analysis}

Analysing teacher performance in complex situations provides a considerable challenge, especially as teachers are often both flexible and adaptable in meeting a variety of purposes. Further, we found at times that they moved fluidly and seamlessly between behaviours addressing a range of personal and socially defined objectives. As has already been discussed, our approach, following Engeström et al. (1999) and Leont'ev (1981), was to begin by identifying from our observations of lessons (using the audio recordings alongside the observation notes) the varied goals and normative conditions (including those implicit in the teachers' discourse and practices) which orientated teachers' work, using prompts such as those in Table 2. This was also done in the interviews, in response to the researcher's recalled observations, teacher planning and examples of student work. In the later part of the second interview, teachers' values and beliefs in relation to their own goals were explored. Goals and norms could be explicit involving, for example, broad motives such as wanting the best for children, specific goals concerning, perhaps, assessed student outcomes (such as test scores), and individual teachers' own goals (perhaps relating to their values and beliefs, career and promotion or 
aspects of their life outside work). But goals could also be hidden in school, department and classroom cultures (defined, after Wenger, 1998, in terms of their dominant norms, discourses and practices) conditioned by, for example, senior manager expectations (in terms of performance management and appraisal) and school inspection frameworks (such as that published by Ofsted in the UK). Goals could also be implicit in teacher preferences and dispositions. We made no assumption all such goals were influential; rather, we sought to identify those we could in the observation and interview data and describe the roles adopted by or assigned to teachers in their pursuit. This was done individually for each teacher, and then comparisons were made across teachers.

Through this process, stated and observed behaviours from all of the data, oriented towards meeting explicit goals and those hidden in norms, discourses and practices, were clustered together to form idealised role types, each stressing the characteristics of certain roles common to most participants. Using Bernstein (1990) as a guide, these clusters were based on roles oriented towards instruction, regulating the division of labour and regulating student socialisation. For each, two role types were constructed, differing in their classification and framing of pedagogic discourse. But although we present this analysis as contrasting pairs, there is no reason why future studies may not require reconstruction as a multi-polar categorisation. Given our intention in this study, stated at the outset, to consider broad processes of mediation, role types were considered in terms of pedagogic process (their form) rather than in terms of specific subject knowledge (content). Participant validation tested their verisimilitude; their resonance with the lived experiences of teachers. In the findings that follow, each role type is described and illustrated with examples.

Finally, the constructed role types were compared with the original data, allowing us to infer the competing, contradictory or incommensurate (differently valuable) positions between which teachers mediated within the affordances and constraints of their working environments and the power relations these mediations embodied. These comparisons follow the presentation of each pair of role types.

\section{Findings}

Role types with instructional goals

Skills coaching. This role type captures those aspects of teachers' practice which focus on developing students' skills with a view towards enhancing their future performance. There is a focus on simple improvements building on earlier achievements, involving much use of repetition and practice. Teachers' strong framing (Bernstein, 1990, 1996) assumes the ability to understand and control students' learning, and they place much faith in the curriculum and student assessments as tools for mapping and locating student development. For example, all of the teachers observed planned and taught highly structured lessons and some, such as 
those in School A, used PowerPoint presentations to regulate pace and content. Teachers outlined learning objectives at the start of lessons and regularly revisited these as they went on. Although claiming that they used ongoing assessment to guide their teaching, some presentations contained prepared slides in which student targets were ticked off as complete as the lesson progressed. Frequent reminders of personal goals and targets, for both academic attainment and school behaviour, were used to engender competition primarily against oneself to achieve personal bests, but also to some extent against others. Again, teachers at School A both included specific reference to National Curriculum-level descriptors and related examples back to pupils in an attempt to help them to appreciate what a move from one level to the next might look like. One reminded her students that, '... people who are getting level $7 \mathrm{~s}$ refer to evidence from their texts' (School A, interview after first observation). Elsewhere, another had two PowerPoint slides, which illustrated how a descriptive text might be assessed at levels 3 and 4, respectively.

Thus, teachers attach much importance to modelling and coaching student activity, providing clear and useful feedback, and in developing skills in a variety of contexts and through a variety of approaches. Whilst all is ultimately directed towards performance in coursework or final examination, wider benefits of having skills for life which can be used flexibly beyond school are also assumed. Indeed, teachers sometimes downplay the importance of the subject by emphasising it simply as a vehicle for developing life skills. Thus, this role type identifies knowledge as weakly classified (Bernstein, 1990, 1996), with teachers seeing skills as transferable across subjects and contexts. This appears to be important to a number of those interviewed, who emphasised the importance of skills development in 'making a difference' to children's lives. In this, teaching deliberately tries to keep boundaries porous; some teachers suggested that, in focusing on skills development, their teaching did not vary from subject to subject.

Subject guiding. In this role type the classification of knowledge is often strong within subject disciplines, so boundary setting is also generally strong, although there is recognition of areas of learning to which several subject disciplines can contribute; how the war poets contribute to our historical understanding of the First World War was an example of this seen in School D.

Practice is at times strongly framed through traditional and authoritative teaching, but can also be less so with teachers also seeing the curriculum as a guide and allowing students to develop their own understandings of the subject and not overly seeking to direct these towards specific correct views. In this most teachers define literature broadly and include an eclectic array of subject matter, and teaching practice situates literature, poetry and the like, indeed all forms of reading, writing, speaking and listening, in their social and cultural contexts and highlights the way they help us to understand our world, the human condition and the 
lived experiences of others. This is exemplified in teacher discourse by notions, referred to by some teachers, that we should teach poetry, for example, 'because it is a central example of the use human beings make of words to explore and understand. Like other forms of writing we value, it lends shape and meaning to our experiences and helps us to move confidently in the world we know and then to step beyond it' (Ofsted, 2007, p. 6). Although there were limited examples of this view, some teachers talked of their love of books and wanting to give to children a love of Shakespeare, and clearly many teachers identified strongly with their subject. One teacher in School B expressed how reading as well as sharing all kinds of literature were important to him, for example, by lending books to colleagues in order to be able to speak about them or being involved in book circles. In this regard he recognised the need for time and space to make reading pleasurable for pupils.

Teacher mediations. In Bernstein's (1990, 1996) terms, these role types are in tension because the first is weakly whilst the second is strongly classified, and the first is strongly framed, whilst the second has elements of both weak and strong framing. Almost all of the practice we observed was like skills coaching. Yet this difference in classification went unnoticed as a tension for nearly all of the teachers who, in terms of explicit educational aims, discussed their own love of literature in a substantive and passionate way, as something of worth in itself, but then expanded on literacy's real educational significance by providing examples of how developing such a love would provide children with a useful tool for the future because literacy is practically important, amongst other things, for employment and for people to access the information they will need in making decisions about their lives.

However, these contrasting aims led to hidden tensions. Although most often the focus of teachers was on literacy as a set of practices involving the physical, the active, process and doing, this was sometimes set against the more strongly classified study of the reified world of meanings, ideas and understandings in and through literature:

Teaching writing skills, teaching reading skills ... You are not teaching whole novels. You are teaching extracts of a novel. You teach the technical aspects of a novel and not just the novel for the sake of enjoying something from encountering English literature. (School B, interview after second observation)

Comparison with the two role types sheds light on two very different ways of knowing. The first is normative, asking students to work within and towards predefined ends. Focusing on the coaching of skills drives the student towards specified goals along well-defined curricular paths. The second is expansive, asking students to widen their thinking through the text and adopt a critical stance to the word. These had clear implications for teachers and could affect the way pupils viewed their relationship with the subject. 
For the first, which dominated, all teachers indicated how important it was to keep moving through the curriculum with pace, and some expressed frustration that this inevitably led to a lack of depth. Further, the weakly classified focus on usefulness and transferable skills sees learning as only valuable as a set of tools. These pull against any notion of taking time to appreciate literature, and looking at great works in depth for their own sake. The necessity for progress at a pace in the first privileges authoritative teaching; highly framed teaching which attempts to lead pupils along a predetermined path. This provides a tension which is only realised when teachers also want pupils to think for themselves. This can be seen in the way in which teachers retain guardianship over right and wrong, even when explicitly claiming that they are trying to develop pupils' critical knowledge. For example, one teacher in School A introduced a new poetry module to run over several lessons and stated that:

... a lot of students lack confidence in order to say what they feel about a poem because it might be wrong, so we're going to try to move away from the idea that there is a right or wrong answer to be able to engage with our own emotions and think how it affects us as individuals. (School A, first lesson observation)

However, moments later, she asked for reactions to the question of what 'poetry is' and as pupils responded she firmly marked the responses she approved of by saying, 'wonderful, absolutely perfect. Images, emotion, isn't it ...', whilst being less enthusiastic about other responses, 'OK, that's interesting ...' (School A, first lesson observation), implicitly grading the worth of answers and their closeness to her ideal.

That there is an order to knowledge development also reflects the assumptions of a coaching development model where discrete skills should be developed and practised before their application to ensure a high-quality performance. So, one teacher's aims for the poetry module involved five areas of expertise that students would acquire (for example, 'to develop your ability to engage with meanings within poems independently' and 'to be able to articulate and justify personal responses to poems') before finally offering pupils the opportunity to 'use emotive imagery as a basis to create your own poetry'. She noted that this was 'a nice bit of the module, mainly we are focusing on reading; we are also going to do some of our own poetry'. This writing appeared almost as an afterthought, once the real work of analysis had been undertaken. Clearly one tension is that weaker pupils may never be allowed to experience the pleasure of reading, writing or speaking for its own sake if they are not deemed ready for this.

\section{Role types with regulatory goals relating to the division of labour}

Entertaining. Here, framing of the division of labour between the teacher and students is strong, with the teacher responsible and held accountable for entertaining the students. Lessons often have the feel of children's television programmes. The emphasis in practice is on the teacher who has to perform and make things 
relevant for the children. Lessons are fast paced and use a variety of presentation techniques, visual, tactile and oral, to engage the children and keep their attention, but also to manage this attention so that students are made aware of what is deemed relevant to their learning and what is not. This role type sees knowledge as delivered by active teachers through various presentational techniques to be consumed by relatively passive pupils. There are multiple tasks and bursts of activity and nothing is dwelt on for too long or in too much depth. For example, the use of PowerPoint dominated many of the lessons observed, and in one school two observed hour-long lessons had 22 slides each. Although the teachers thought of their lessons as interactive, in practice they tended to create a 'performance' designed to transmit information; interaction was superficial and although teacher speech was questioning and seemed to encourage dialogue, questions were either treated rhetorically or replied to by assenting nods or single words, and so communication was largely one way.

Everybody is kept happy: children who respond incorrectly to questions are not told so as this might be seen as a 'put down'; rather, they are simply told to have another go or their answer is passed over quickly. For example, one teacher in School C asked the same question of several children. Each answered incorrectly, and she repeated their answer and said 'Has anyone else got an answer?' When the correct answer was given she said 'Yes', and developed the child's answer into a lengthy explanation. Extending the entertainment metaphor, this might be thought of like the stand-up comedian who appears to use material from the audience, but who, in practice, is manipulating this for his or her own comedic ends as part of the performance.

In this role type, then, the teacher is centre stage and the pupils are the audience (which is similar to the findings of Pratt, 2006). Praise is liberally offered to pupils, largely for the making of contributions, rather than for their quality. Misbehaviour is put down to lack of engagement. Thus, the teacher-pupil relationship is akin to one of serving customers; as consumers the students have rights but little responsibility.

Supervising. The teacher supervises and closely monitors the children as they do their work, and so again framing is strong, with the teacher responsible for ensuring students' labour and holding students to account. Here, the relationship is one of manager and worker, with the students who are the latter having responsibility but few rights. This work involves producing something, and the quality of the product is emphasised. Work is not always enjoyable; it can be challenging and hard. The children are responsible for doing work and the teacher is responsible for organising the children so that they know what to do and can complete their work effectively and with little confusion, and for monitoring and supervising this process. Learning is taken for granted; being synonymous with working.

So, for example, many lessons observed were highly structured with a flurry of different activities. Children were clearly informed about the learning outcomes, 
activities were clearly introduced and a time was set: 'you've got four minutes to get this done' ... 'two minutes to get out your books or paper' (School C, second lesson observation). The teacher engaged in managing students' labour closely.

In a softer version of this role type, the teacher initiates activity but then withdraws to a supporting or facilitating role, in the belief that pupils will learn through engagement with the task. Thus, their framing of the division of labour is weaker. The teacher remains on hand to offer experience and guidance, but within a context of co-construction, rather than projection, of knowledge. Assessment is seen as important in this role type, as it is in others, but here the focus is on the process of listening to pupils in order to quality-assure their work rather than to establish achievement.

Teacher mediations. These role types concern the distribution of labour within the classroom, and entertainment dominated the lessons observed. Whilst both role types have strong framing, this is less apparent in supervising. This is because accountability is clearly centred on teachers in the first, but moves towards teachers holding students accountable in second. Comparison of the two role types with the original data sheds light on classroom tensions where, as the locus of responsibility shifts implicitly from the teacher to the children, the pace of the lesson inevitably shifts, as does the amount of effort required from the children. In this regard, teachers complained that children were not independent enough and needed to be nagged, or that their enthusiasm during presentations was not matched by their application to independent work. For example, one teacher said:

There is a shift towards the teacher and away from the student. And, you know, to the extent we are chasing up course work three weeks off the deadline, we ring at home, we go to the home to pick it up-we are ultimately accountable. So I think, you know, yes, support is needed, but it's got to be the right kind of support, at the right level, at the right time. (School $\mathrm{B}$, interview after second observation)

However, his colleague felt that children expected not to fail and received too much support, but saw it as his job to help them develop and offer the right intervention.

Some teachers attempted to reconcile the tensions brought by shifting responsibilities by moderating their expectations of the students, evaluating students largely in terms of their willingness to work rather than focusing too much on the quality of that work:

I think it was a good, solid lesson. There was nothing too kind or fancy, nothing too show-offy in there. I think they enjoyed the activity, they were engaged. So from that part it was enjoyment and engagement. And there was a satisfactory degree of learning, at least from my point of view. (School B, interview after first observation)

However, a few teachers rejected an entertainment role for themselves, focusing more on their instructional role, and suggested a link between success and engagement in learning: 
There is a miscomprehension engagement means fun, means lively, means activity, it means doing things ... but I think engagement is the students being comfortable and confident, knowing that they can achieve. It is setting just the right level of challenge ... at the same time, if you set challenges too easy, if teachers think if it is easy the kids will like it and they will do it-but, I think it is the complete opposite, I think. If they find it too easy, they'll switch off ... it is just finding the right level of challenge ... and pitching it just above, where they are comfortable ... and that is what engages them. (School B, interview after first observation)

\section{Role types with socialising goals}

Hierarchical. Here, framing is strong as teachers emphasise order and control, but also wanting the best for the children in a concerned and caring way. This role type is often about enforcing school structures of control placed on children such as uniforms and timetables and, at a classroom level, class rules, lessons that are tightly prescribed, and involve the extensive use of resources such as PowerPoint presentations, and strict monitoring regimes using inflexible assessment systems. Implicit in all such structures is that it is in children's best interests to comply with them:

\footnotetext{
But I think the kids need to be challenged. They almost appreciate the challenge. Because when you talk to them it is interesting that the teachers which they've got the least amount of respect for that are the teachers which would let them to get away with anything. (School B, interview after second observation)
}

In this quote, as in others illustrating this role type, it is respect for the teacher that is important.

In a weaker version of this hierarchical relation, teachers see themselves as counsellors and offer concerned advice to children. However, the teachers observed most often adopted a hierarchical stance when they had a behavioural issue to deal with.

Democratic. This is more often illustrative of younger teachers' roles. Framing appears weak as teachers position themselves in their practice alongside the children and often suggest that they are working together for a greater good-normally the ultimate success of the children. But this is apparent, as Bernstein (1975) suggests, because to concentrate only on teachers' explicit framing would be to ignore the less visible framing influence of existing norms and expectations on pupils' behaviours. Nevertheless, teachers accept a degree of responsibility in advising without telling students how to proceed, but counter this by acting playfully, showing a willingness to have fun and let their hair down from time to time.

In this role type the notion of mutual respect is important:

Also treating the students with respect ... treat them like adults ... answering their questions. You know, if they got questions to ask me, no matter how daft and then 
how off task it is, I'll try to answer it for them. (School B, interview after first observation)

As such, a number of teachers suggested that it is through showing the students respect that you gain respect for yourself as a teacher.

Teacher mediations. The first of these role types is strongly framed; the second appears weakly framed. Explicit tensions were evident when teachers noticed contradictions. For example, some felt uncomfortable enforcing school structures or norms because they recognised that either or both of these contradicted other aspects of their practice or their espoused educational beliefs; one teacher was dismayed by the school's emphasis of uniform and rules, which she felt was in opposition to her belief in democratic schooling and her desire to allow children to express themselves and have a say in school decision making. However, teachers' framing was itself sometimes contradictory, as in the following example where a teacher discussed having a positive and mutually respectful relationship, but then suggested:

It is my philosophy is about that relationship with the student. And if I had a good enough relationship I could pretty much get them to do anything and putting it frankly, pretty much learn anything I want them to do. (School B, interview after first observation)

This view expressed of having complete control over children's learning seems very much at odds with a belief in mutual respect.

Certainly it was the desire of some teachers interviewed that they be seen by children as 'normal' people, often so that they would be regarded as accessible, but also so that students could identify with them and see them as role models:

The kids see me in the gym or running or, you know, they see me outside the school. I don't put up a front when I am in school. What you see at the school is what you see on the street or when you walk past my house and I'm having a barbeque. That the fact that it is a community school and that they can see you doing a whole host of different things. Again they feel comfortable with you as a person. I don't want to be seen just as the teacher. I want to be seen as a person they can relate to, which has other interest and engage in the same as they might have and the same as their parents may have. (School $\mathrm{B}$, interview after first observation)

For these teachers their espoused position was mostly for a democratic relation, although across our observations we found the framing of socialising roles in practice to be balanced between strong and apparently weaker. Yet in their considerations little attention was given to the influence of existing norms and expectations on pupils' behaviours and in practice dominant roles associated with instruction and the division of labour were both highly framed.

We have argued for roles as a unit of analysis because they are co-constructed by teachers and pupils together. In this regard it is worth considering whether teachers' socialising roles worked to keep things flowing smoothly, encouraging 
students to reciprocate teachers' roles concerning instruction and the division of labour, a point we will return to in the discussion. For Doyle (1983, 1986), pupils use their cooperation or its withdrawal to encourage teachers towards their preferred ways of working. Whilst we found little evidence for this in the present study - indeed, it was not something we were looking for at the outset-a significant feature of situated English teaching we did identify was that when English teachers were in the flow of lessons they moved smoothly between behaviours reminiscent of different role types in a continuous and comfortable style, easily and without reflecting any tensions between them; there is fluidity in their activity. For example, one teacher observed began the English lesson by settling the children down in a caring but firm manner (a hierarchical relation) but then, after a few minutes, with a joke she introduced a fun activity based on a children's television programme, which the class worked at in groups competing with each other (an entertaining relation). She urged them to work quickly ('go, go, go!'), counted them down to the completion of their activity each time (' $5,4,3,2$, 1, stop!'), and accepted all answers in a friendly and engaging manner. However as soon as one group began to get too lively she told them how their behaviour would spoil things for everyone (a hierarchical relation), and then suggested the groups organise themselves better so all children could take part (a supervising relation). At the end of the activity she focused the children on what they had learnt and coached them on how they could have done the activity better and what the general lessons were for their future writing performance (a skills coaching relation). The movement between behaviours suggesting different role types, each with a different goal orientation, was seamless and almost dance-like in its relation to the reciprocal behaviours of pupils.

\section{Discussion}

In this paper we have described competent lower secondary school English teaching in South West England as a process of mediation between roles conducive to teachers and their students meeting varied and sometimes contradictory goals. We have identified in broad terms the competing goals that teachers mediate between and the explicit and hidden tensions that result. To understand the interactions of complex goals towards which teachers' work is oriented, we have clustered goaldirected behaviours (which we have called roles) into six idealised areas and then compared these to the original data to cast light on the contradictory positions and subsequent tensions to which they lead.

It is important to note that we are not suggesting that teachers' behaviours can literally be described in terms of entirely discrete roles. Role types, as metaphorical constructs, at times overlap and may sometimes be indistinguishable in practice. Socialising role types, for example, may be seen as framing the supervision of work to encourage pupils to cooperate. We have also illustrated in our findings how practice akin to different role types can make use of resources like PowerPoint in similar ways to address different contingent goals. But in actuality the teachers 
observed moved smoothly between different roles in a continuous and comfortable style, easily and without reflecting any tensions between them. Thus, we contend, the usefulness of our analysis is not in identifying idealised role types per se; it is in using these as a lens to infer areas of mediation and hence tensions in practice and identifying consequent implications.

By describing roles we have highlighted the form rather than the content of pedagogic processes, and in this it is important to acknowledge the reciprocal nature of student and teacher activity. However, as this study has focused only on teachers, descriptions are inevitably partial; it is intended that future studies will seek to redress this. Nevertheless, we believe that these early findings provide a glimpse of the worth of further and more comprehensive contextual explorations of teaching using this same approach. These could allow comparisons to be made of how teaching varies across contexts; perhaps on the basis of subject, age of children, type of school and from one country to another. In the long term we see this work as providing the basis for developing a better understanding of cultural variation in teaching. But in the short term we feel that we can also draw some tentative conclusions from this study, and it is to these that we now turn, beginning with a consideration of the influences across which teachers mediate.

We assert that competing goal-oriented roles, significant to particular educational circumstances, emanate from various and sometimes contradictory local, national and perhaps broader social and cultural influences on teachers' practice. The skills coaching and entertaining role types resonated closely with what was most often seen in the practices of all participants, teaching as a form of supervising was observed on a significant number of occasions, whilst that reflecting liberal humanist subject guiding was rarely seen. Given the degree of centralised control and regular intervention in schools in England at a national level it is not surprising that teachers shared many similarities. Teachers interviewed predominantly identified with coaching skills development for lifelong learning rather than with the discipline of English. This was not unexpected: the rhetoric of skills development has been central to policy development in England for over a decade, with subjects such as English renamed literacy so as to emphasise their contribution to lifelong learning and the workplace. Similarly, these teachers identified with a strong role for themselves within the division of labour; whether akin to entertaining or supervising, they play a central part in guiding children's learning. Again this is not unexpected, given the importance placed on teachers in Ofsted school inspections and in documentation, guidance and training associated with the national strategies in English (such as the Key Stage 3 Strategy, DCSF, 2009); a widely promoted initiative focusing on learning when managing behaviour (TDA, 2007) might also have been influential.

Often noticeable and explicit tensions arise at a local level because teachers are positioned by various normative structures in their daily interactions to adopt roles that are contrary to their or their students preferred ways of working or challenge their espoused identities and beliefs. In one example, the requirement to police school uniform assigned a hierarchical position to a teacher who stated that she 
felt she should act more democratically and disliked taking this role. Similarly, the heavy emphasis in testing on content was disliked by teachers wanting to focus on teaching skills (which is interesting in relation to our other findings); they accepted as necessary but with frustration the position assigned to them by the assessment system. Finally, school accountability systems based on the scrutiny of children's work meant that teachers had to supervise the completion of this; some stated that they would far rather be motivating and inspiring them. Thus, assigned positions (when noticed) can be resented (Bourdieu, 1993, 1996), although we found no evidence of active resistance. Of course, many assigned positions are accepted because teachers want to be positioned thus and there is no conflict. But other potential tensions can go unnoticed. In the present study this included those between skills coaching and expansive subject learning, perhaps because the first role dominated to such an extent. So these, along with tensions expressed by teachers acquiescing to school norms, had little bearing on practice, sidelining opportunities for students' democratic expression, appreciation of learning for its own sake and expansive thinking.

Further research is needed to explore and compare teaching through the lens of roles and idealised role types. This includes children's complicity in reciprocally defining their and their teachers' goals through their goal-oriented behaviours or roles. By adopting a role, tacitly or deliberately, one positions oneself both towards the physical and social environment and towards other participants in that setting. The other participants reciprocate in their roles, positioning themselves, for example, as cooperative or resistant. Boaler (2002) has found that students positioned repeatedly in particular ways become accustomed to position themselves thus. So when knowledge is emphasised by teachers, successful students tend to position themselves as receivers of knowledge and identify themselves as 'knowers'. The concern of students tends to be with doing things the 'right way', maintaining traditions and standards, following classic approaches to solving problems, seeking a 'true' interpretation of ideas and so on. However, when the process of engaging in subjects as ways of knowing is emphasised by teachers, then successful students tend to identify themselves with seeing the world from the perspective of that subject. This allows students greater freedom for exploring, being innovative, finding alternative interpretations and so on. Thus, understanding teachers' roles is central to understanding the student experience and how students' behaviours become structured (Bourdieu, 1993, 1996); there are regularities not only in the ways individuals or groups apprehend, encounter and act in the world, but also in the ways they give meaning to it, often without their awareness.

Thus, Boaler's (2002) work suggests that it is likely students will adopt positions defined by those their teachers take towards them, and when this happens repeatedly the students will become disposed to adopt that same position in similar circumstances. Each idealised role type reported here can be thought of as illustrating how students can be positioned and develop dispositions. The dominance in this study of roles akin to entertaining and skills coaching might therefore be reciprocated by students disposed to being entertained or coached-and what- 
ever their benefits, both of these positions are dependent and potentially passive. Whilst this is a speculative proposition, in our view there is some worth in exploring whether such processes and student behaviours are identifiable.

But it is also likely that at times students exert a strong influence on the goaloriented roles teachers take, and exploring this influence will also be important in future studies. Earlier, we supposed that this might involve a dance of cooperation and resistance between teachers and pupils in relation to instruction and the division of labour, managed through socialising roles. In this regard, it is interesting that many of the competent teachers observed in this study moved seamlessly between various roles despite potential explicit and hidden tensions between them. Perhaps this was because their primary concern was in engaging students, with all of their work strongly framed to this end. So, many teachers espoused a belief in a relatively equal and democratic relationship with their children, like that of a critical friend, and the frequency with which they adopted roles akin to hierarchical or democratic types was balanced. But we have indicated that the weak framing of democratic roles is only apparent; norms and expectations are highly influential. Further, in practice we saw largely strong framing of instruction and the division of labour. Hence, for the most part, it seems likely that teacher framing was consistently strong and so the dance, under the direct control of teachers, was fluid and smooth with little need for recourse to socialising behaviours. Also, in terms of classification, almost all of the practice observed was weakly classified. So, in practice, the potential for explicit and hidden tensions was not, for the most part, realised. Nevertheless, when democratic relations were adopted, it is possible that they kept lessons flowing by encouraging solidarity between teachers and students towards a common purpose; hierarchical relations may have done so more through authority and the threat of sanction.

It is also possible that those goal-oriented roles most adopted by teachers were also those preferred by students, even ignoring the possibility that students learned to be disposed towards such roles. Bernstein (1975) suggests that it is likely that many pupils, particularly those from working-class backgrounds, will favour learning presented as skills as opposed to that which is more esoteric, because this makes practical sense to them and is understood as relevant to their own lives; a case of horizontal discourse (Bernstein, 1999). It is also possible many pupils may favour being entertained over being supervised; as we saw, often students' enthusiasm during teacher-led presentations was not matched by their application to independent work. Teachers seeking to avoid resistance might well, for the most part, stick with such roles, which perhaps accounts for some of the success of behavioural approaches based in making learning practical and relevant (TDA, 2007). This might also help to explain why another national emphasis on personalised learning (DCSF, 2007), which attempts to increase the responsibility pupils take for their own learning, seems to have had less effect. Interestingly, some of the teachers we interviewed suggested that greater independence could be encouraged by their micro-managing students' work, although others saw shifting responsibility to students as more problematic. Thus, it is possible that potential tensions would 
be more evident, with teachers increasingly adopting socialising roles, were more responsibility assigned to pupils, the ambiguity of class work increased allowing pupils greater freedom of choice or teachers to engage pupils in a vertical discourse (Bernstein, 1999) making more abstract and esoteric demands. Nevertheless, to repeat, these suggestions, whilst informed, are partly conjecture; certainly further studies focusing on reciprocal student roles are needed, particularly across schools and classrooms with different profiles in terms of social advantage and achievement.

Together, the national and local influences described earlier lead teachers, explicitly and tacitly, to recognise and prioritise some goals above others, especially when time and resources are limited. Hence, goals are contingent, as is teaching which addresses them. And, as we have just discussed, circumstances require teachers to engage in an ongoing mediation between different factors in negotiation with their students. We call this process situated English teaching.

Discussion of the findings of a study such as this can only make cautious suggestions for theoretical developments, raise possibilities for policy consideration or point to potentially fruitful areas for future research. So far, we have begun to address the third of these, but in relation to teacher development many further questions for research arise with direct implications for practice, some of which are: How do novice teachers gain situated competence? Does it help to structure the experiences of novice teachers so they gradually encounter a wider range of goals? Which combinations of teacher roles are most effective in encouraging active pupil roles?

In relation to the other two, first, Wenger's (1998) theoretical descriptions imply that communities of practice are coherent and relatively clear about their goals. The findings here challenge this. Participants in classroom communities move, often fluidly and frequently, between various reciprocally defined roles. These roles reflect the many goals across which participants have to mediate; socially shared and individual, visible and invisible, each with associated discourses and practices and conditioned by socialised tacit and explicit norms and expectations.

There is a message too for policy makers. Our findings indicate that macrosocial policy has a significant impact on the micro-social. The relation of policy to practice is well documented; Bourdieu (1986) sees links across levels from policy to practice, as do Ball and Bowe (1992), whose analysis in terms of a policy cycle makes a clear distinction between intended policy, actual policy and policy-in-use. In this, policy-in-use is not simply the application of policy to practice, as we have indicated. Given the complexity of situated teaching described above, it is no wonder top-down reform is often problematic with unforeseen consequences. In this, our research stands as a caution to policy makers to consider both form and content. Whilst further research is needed to give greater confidence to our findings, we offer the following tentative conclusions. It appears that instrumental policies encourage instrumental teaching, which may lead students to see knowledge largely in instrumental terms. Further, policies that place responsibility on teachers for student learning encourage teaching approaches that promote passive students. 
These are surely outcomes as significant as the raised student exam scores that these policies intended to achieve.

\section{References}

Ball, S.J. (2006) Education policy and social class: the selected works of Stephen Ball (London, Routledge).

Ball, S.J. \& Bowe, R. (1992) Subject departments and the 'implementation' of National Curriculum policy, fournal of Curriculum Studies, 24(2), 97-115.

Beijaard, D. \& Verloop, N. (1996) Assessing teachers' practical knowledge, Studies in Educational Evaluation, 22(3), 275-286.

Berlak, A. \& Berlak, H. (1981) Dilemmas of schooling. Teaching and social change (London, Methuen).

Bernstein, B. (1973) Class, codes and control (vol. 2) Theoretical studies towards a sociology of language (London, Routledge \& Kegan Paul).

Bernstein, B. (1975) Class, codes and control vol. 3 Towards a theory of educational transmission (london, Routledge \& Kegan Paul).

Bernstein, B. (1990) The structure of pedagogic discourse (London, Routledge Falmer).

Bernstein, B. (1996) Pedagogy, symbolic control and identity: theory, research, critique (London, Taylor \& Francis).

Bernstein, B. (1999) Vertical and horizontal discourse: an essay, British fournal of Sociology of Education, 20(2), 157-173.

Billett, S. (2001) Knowing in practice. re-conceptualising vocational expertise, Learning and Instruction, 11(6), 431-452.

Boaler, J. (2002) The development of disciplinary relationships: knowledge, practice and identity in mathematics classrooms, For the Learning of Mathematics, 22(1), 42-47.

Bourdieu, P. (1986) Forms of capital, in: J. Richardson (Ed.) Handbook of theory and research for the sociology of education (New York, Greenwood Press).

Bourdieu, P. (1993) The field of cultural production (London, Sage).

Bourdieu, P. (1996) The state nobility-elite schools in the field of power (Oxford, Polity Press).

Broadfoot, P.M. \& Osborn, M.J. (1993) Perceptions of teaching: primary school teachers in England and France (London, Cassell).

Croll, P. (Ed.) (1996) Teachers, pupils and primary schooling: continuity and change (London, Cassell).

Crotty, M. (1998) The foundations of social research: meaning and perspective in the research process (London, Sage).

Christie, D. (2003) Competences, benchmarks and standards in the teaching profession, in: T. Bryce \& W. Humes (Eds) Scottish education (2nd edn) (Edinburgh, Edinburgh University Press).

Day, C. (1999) Developing teachers: the challenges of lifelong learning (London, Falmer Press).

DCSF (2007) The Children's Plan: building brighter futures. Available online at: https:// www.education.gov.uk/publications/standard/_arc_SOP/Page11/CM\%207280 (accessed 1 December 2011).

DCSF (2009) The National Strategies. Available online at: http://nationalstrategies.standards.dcsf.gov.uk/secondary (accessed 27 November 2009).

DfEE (1998) Teaching: high status, high standards (London, Department for Education and Employment).

Doyle, W. (1983) Academic work, Review of Educational Research, 53, 159-200. 
Doyle, W. (1986) Classroom organisation and management, in: M. Wittrock (Ed.) Handbook of research on teaching (New York, Macmillan).

Dreyfus, H.L. \& Dreyfus, S.E. (1986) Mind over machine: the power of human intuition and expertise in the era of the computer (Oxford, Basil Blackwell).

Ellis, V. (2007) Subject knowledge and teacher education (London, Continuum).

Engeström, Y., Miettinen, R. \& Punamäki, R.L. (1999) Perspectives on activity theory (Cambridge, Cambridge University Press).

Fish, D. (1995) Quality learning for student practice. university tutors' educational practice (London, David Fulton).

Glaser, R. (1987) Thoughts on expertise, in: C. Schooler \& W. Schaie (Eds) Cognitive functioning and social structure over the life course (Norwood, NJ, Ablex).

Glaser, R. (1990) Expertise, in: M.W. Eysenk, A.N. Ellis, E. Hunt \& P. Johnson-Laird (Eds) The Blackwell dictionary of cognitive psychology (Oxford, Blackwell).

Greeno, J.G., Collins, A.M. \& Resnick, L.B. (1996) Cognition and learning, in: D. Berliner \& R. Calfee (Eds) Handbook of educational psychology (New York, Macmillan), $15-41$.

Harlen, W. (1997) Teachers' subject knowledge and understanding and the teaching of science at the primary level, Science Teacher Education, 19, 6-7.

Kelly, P. (2006) What is teacher learning? A socio-cultural perspective Oxford Review of Education, 32(4), 505-519.

Lave, J. (1991) Situated learning in communities of practice, in: L. Resnick, J. Levine \& S. Teasley (Eds) Perspectives on socially shared cognition (Washington, DC, American Psychological Association).

Lave, J. \& Wenger, E. (1991) Situated learning: legitimate peripheral participation (Cambridge, Cambridge University Press).

Leont'ev, A.N. (1981) The problem of activity in psychology, in: J.V. Wertsch (Ed.) The concept of activity in soviet psychology (New York, M. E. Sharpe).

Lowman, J. (1996) (1996) Characteristics of exemplary teachers, New Directions for Teaching and Learning, 65, 33-40.

Marshall, B. (2000) English teachers: the unofficial guide—researching the philosophies of English teachers (London, Routledge Falmer).

Marshall, B. (2003) The write kind of knowledge in English, English Teaching: Practice and Critique, 2(3), 83-94.

Medwell, J., Wray, D., Poulson, L. \& Fox, R. (1998) Effective teachers of literacy. Available online from: http://www.leeds.ac.uk/educol/documents/000000829.htm (accessed 24 November 2009).

Moats, L. (1999) Teaching reading is rocket science. what expert teachers of reading schools know and be able to do (Washington, DC, American Federation of Teachers).

Ofsted (2007) Poetry in schools: a survey of practice 2006-7 (London, Ofsted).

Osborn, M.J. (1996) Teachers as adult learners: the influence of the national context and policy change, in: G. Claxton, T. Atkinson, M. Osborn \& M. Wallace (Eds) Liberating the learner (London, Routledge).

Osborn, M. (2006) Changing the context of teachers' work and professional development: a European perspective, International fournal of Education Research, 45, 242-253.

Osborn, M., Broadfoot, P., Planel, C. \& Pollard, A. (1997) Social class, educational opportunity and equal entitlement: dilemmas of schooling in England and France, Comparative Education, 33(3), 375-393.

Osborn, M., Broadfoot, P., McNess, E., Planel, C., Ravn, B. \& Triggs, P. (2003) A world of difference. comparing learners across Europe (Maidenhead, Open University Press). 
Osborne, J. \& Simon, S. (1996) Primary science. past and future directions, Studies in Science Education, 26, 99-147.

Pea, R. (1993) Learning scientific concepts through material and social activities: conversational analysis meets conceptual change, Educational Psychologist, 28(3), 265-277.

Pratt, N. (2006) Interactive teaching in numeracy lessons: what do children have to say? Cambridge fournal of Education, 36(2), 221-235.

Schön, D. (1983) The reflective practitioner: How professionals think in action (New York, Basic).

Schön, D. (1987) Educating the reflective practitioner (San Francisco, Jossey-Bass).

Shulman, L. (1986) Those who understand: knowledge growth in teaching, Educational Researcher, 15(2), 4-14.

Shulman, L. (1987) Knowledge and teaching: foundations of the new reform, Harvard Educational Review, 57(1), 1-22.

Sternberg, R.J. \& Horvath, J.A. (1999) Tacit knowledge in professional practice (London, Lawrence Erlbaum).

Summers, M. (1994) Science in the primary school: the problem of teachers' curricular expertise, The Curriculum fournal, 5(5), 179-193.

Tatto, M.T. \& Mincu, M. (2009) Reforming teaching and learning: comparative perspectives in a global era (Rotterdam: Sense).

TDA (2007) Behaviour4Learning. Available online at: http://webarchive.nationalarchives. gov.uk/20101021152907/http://www.behaviour4learning.ac.uk (accessed 1 December $2011)$.

TTA (2002) Qualifying to teach: handbook of guidance (London, Teacher Training Agency).

Turner-Bisset, R. (2001) Expert teaching: knowledge and pedagogy to lead the profession (London, David Fulton).

Weber, M. (1949) Objectivity in the social sciences and social policy, in: E. A. Shils \& H. A. Sinch (Eds) The methodology of the social sciences (New York, Free Press).

Weber, M. (1970) Religious rejections of the world and their directions, in: H.H. Gerth \& C.W. Mills (Eds) From Max Weber: essays in sociology (Oxford, Oxford University Press).

Wedege, T. (2002) 'Mathematics - that's what I can't do': people's affective and social relationship with mathematics, Literacy and Numeracy Studies: An International fournal of Education and Training of Adults, 11(2), 63-78.

Wenger, E. (1998) Communities of practice. learning, meaning and identity (New York, Cambridge University Press).

Wyatt-Smith, C. \& Gunn, S. (2007) Evidence-based research for expert literacy teaching (Melbourne, Department of Education and Early Childhood Development). 